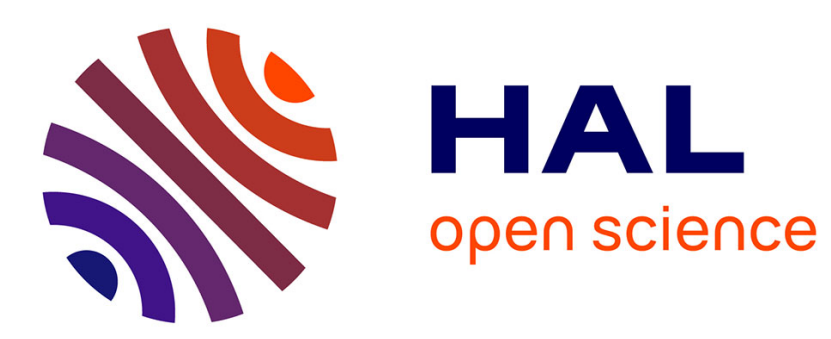

\title{
Identification of acoustic moving sources in the context of a road vehicle at pass-by: A numerical comparison
}

Rémi Cousson, Marie-Agnès Pallas, Quentin Leclère, Michel Bérengier

\section{To cite this version:}

Rémi Cousson, Marie-Agnès Pallas, Quentin Leclère, Michel Bérengier. Identification of acoustic moving sources in the context of a road vehicle at pass-by: A numerical comparison. Forum Acusticum, Jun 2017, BOSTON, United States. Acoustical Society of America, Forum Acusticum, 5 (141), pp.3883, 2017, 10.1121/1.4988696 . hal-01627750

\section{HAL Id: hal-01627750 \\ https://hal.science/hal-01627750}

Submitted on 13 Nov 2017

HAL is a multi-disciplinary open access archive for the deposit and dissemination of scientific research documents, whether they are published or not. The documents may come from teaching and research institutions in France or abroad, or from public or private research centers.
L'archive ouverte pluridisciplinaire HAL, est destinée au dépôt et à la diffusion de documents scientifiques de niveau recherche, publiés ou non, émanant des établissements d'enseignement et de recherche français ou étrangers, des laboratoires publics ou privés. 
Identification of acoustic moving sources in the context of a road vehicle at pass-by: a numerical and experimental comparison
IFSTTAR
R. Cousson ${ }^{1,2}$, M.-A. Pallas ${ }^{1}$, Q. Leclère ${ }^{2}$, M. Bérengier
IFSTTAR-AME/LAE, Bron, France - 2 INSA Lyon-LVA, Villeurbanne, France
$\checkmark$ iRSTV
Trelabera

Abstract $\mathrm{n}^{\circ} \mathbf{2 7 1 3 4 2 9}$

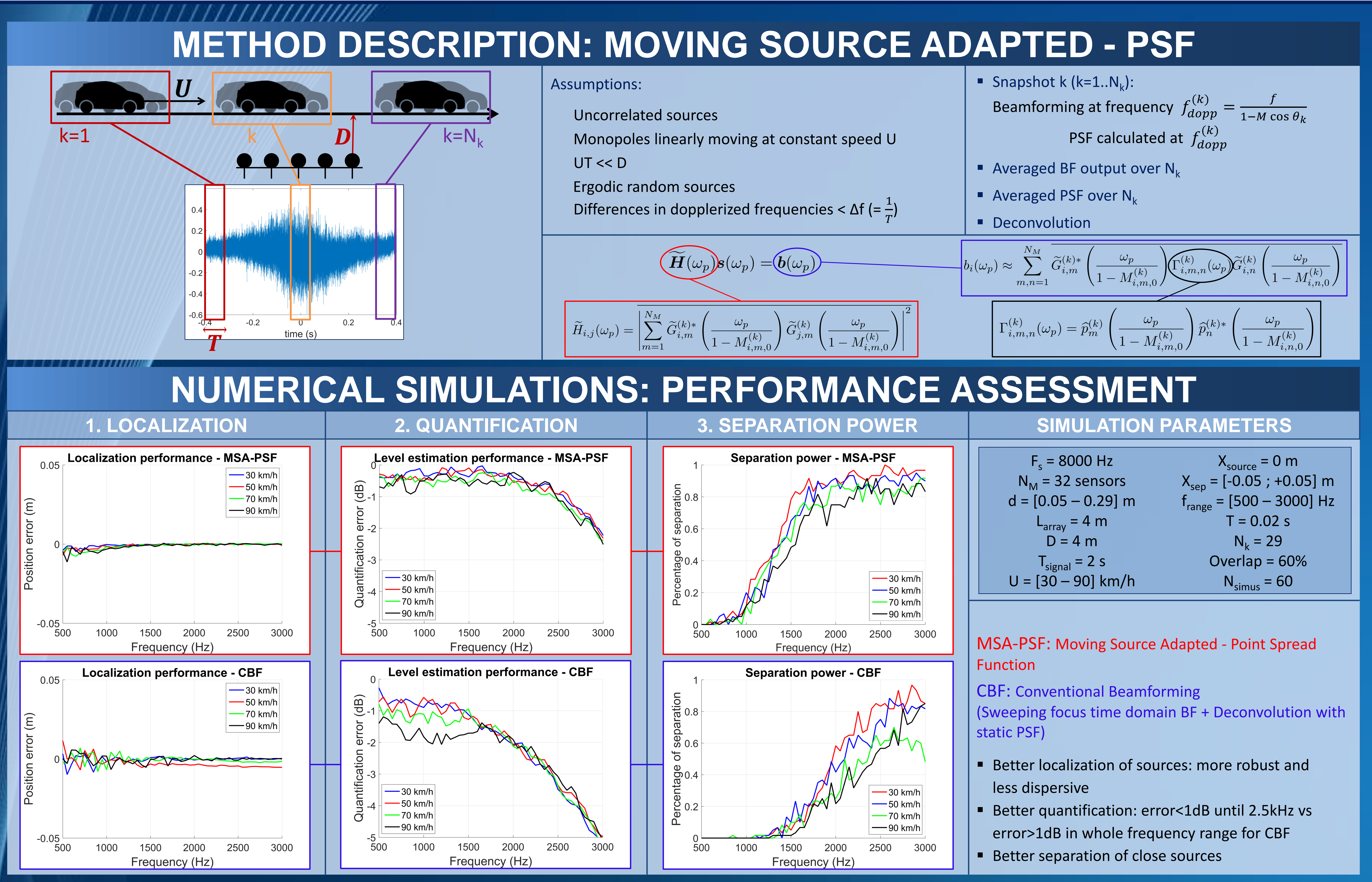

ACADEMIC EXPERIMENT

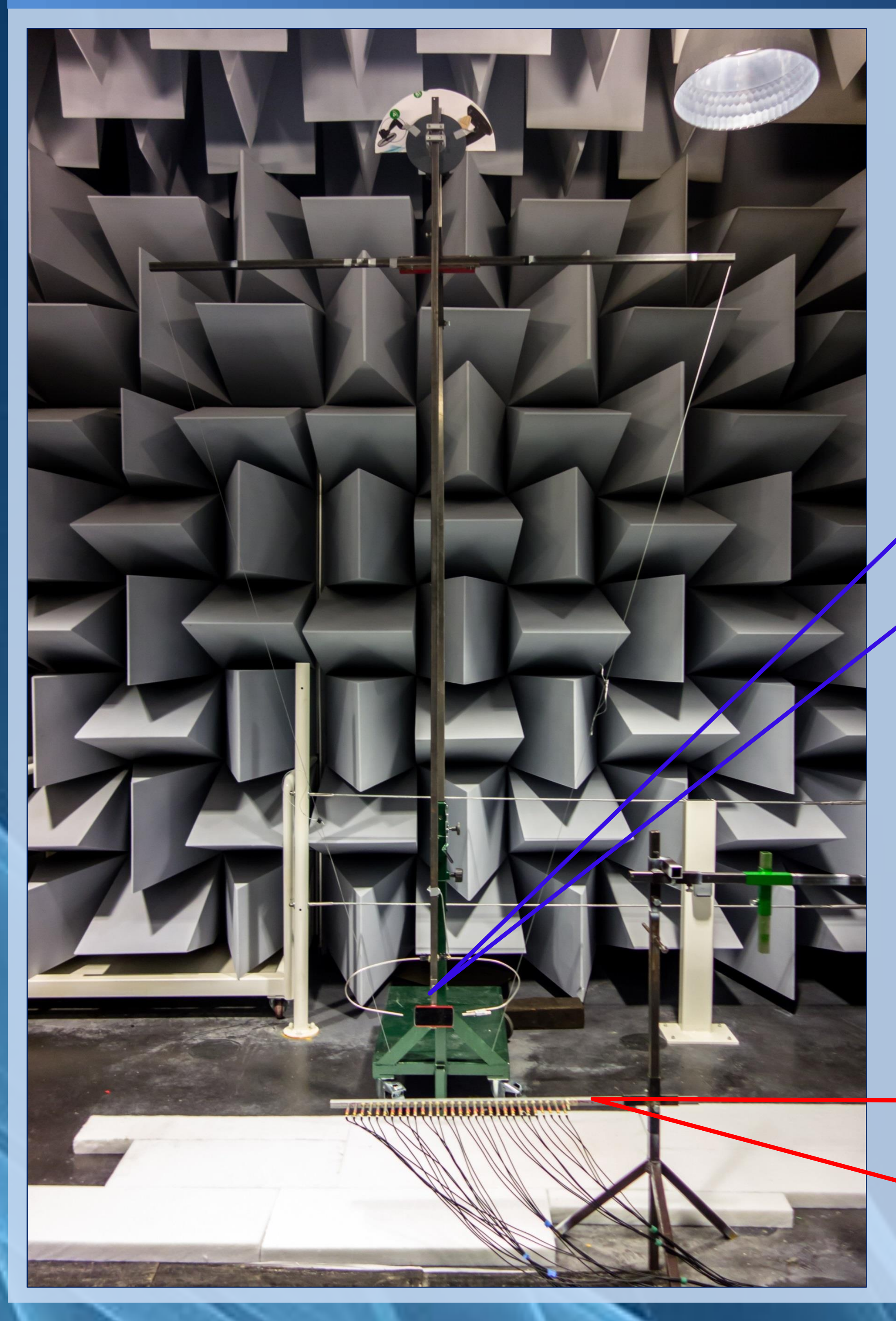

REFERENCES

[1] V. Fleury, J. Bulté, Extension of deconvolution algorithms for the mapping of moving acoustic sources, J. Acoust. Soc. Am., Vol. 129, 1417-1428

[2] B. Oudompheng, Array processing for the localization and the contribution of acoustic sources of passing-by ship using a

[3] P.M. Morse, K.I. Princeton University Press, 717-726 (1992)

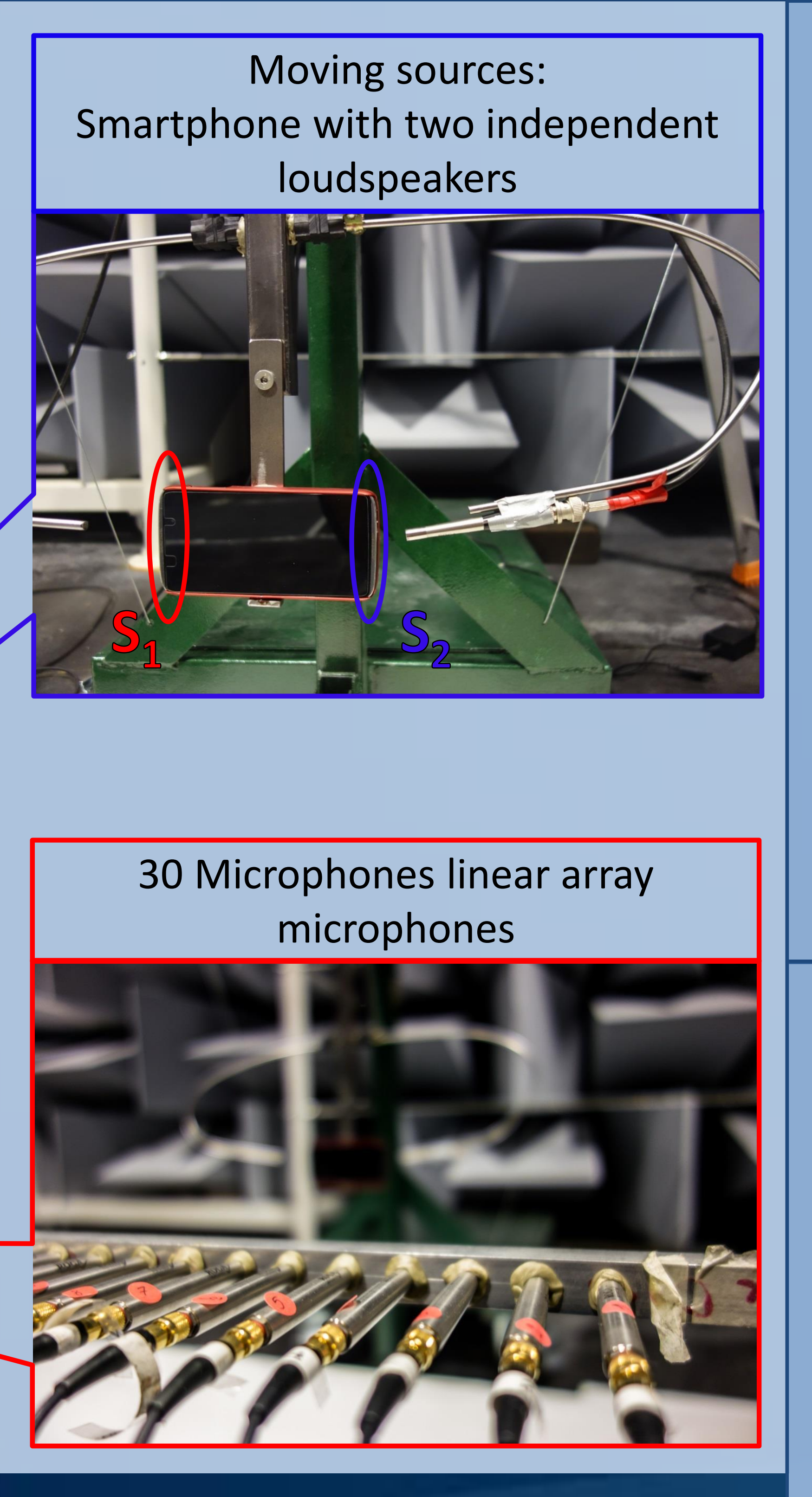

PERSPECTIVES

Real pass-by condition measurements

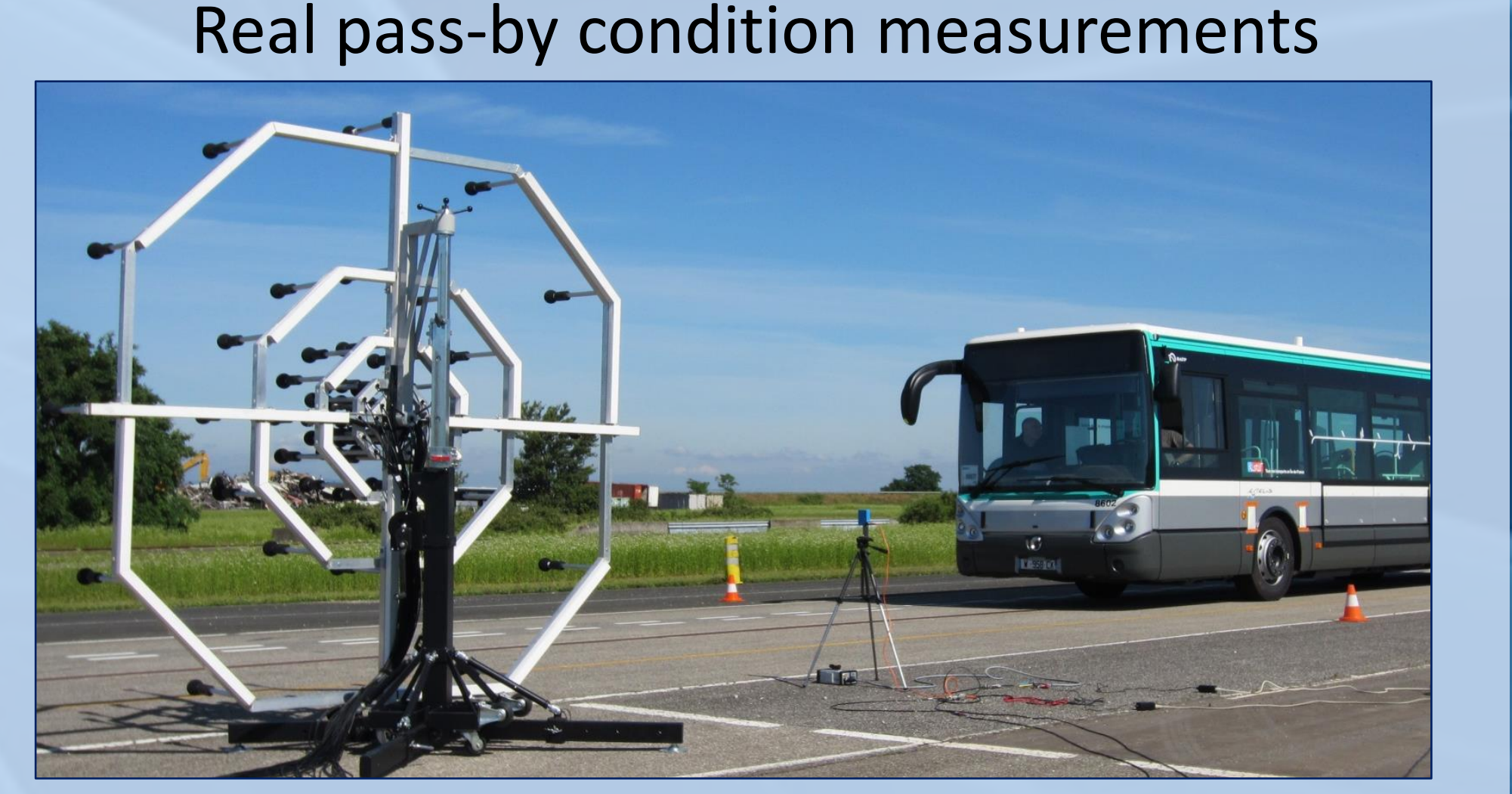

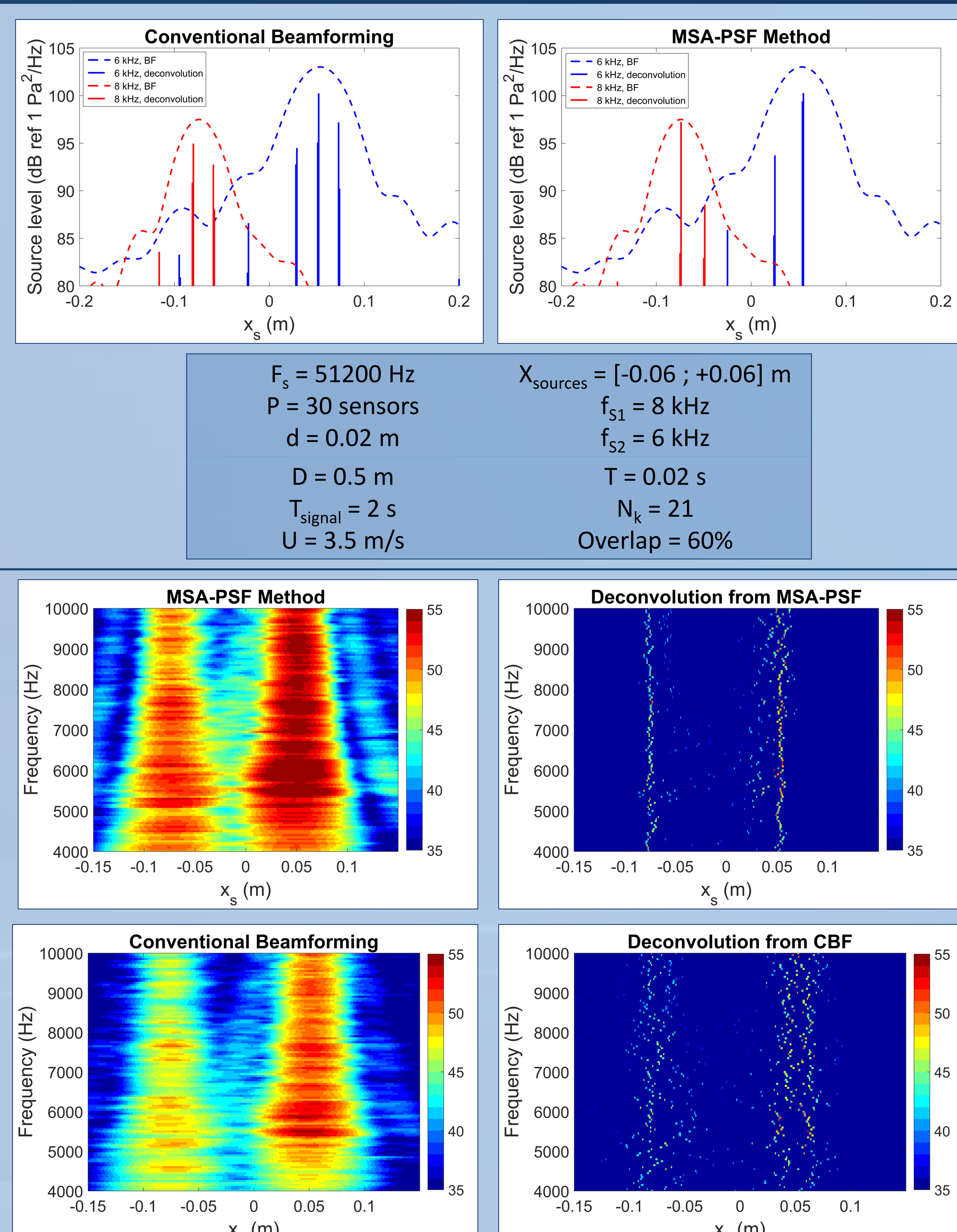

